\title{
ANALISIS KEBUTUHAN AIR KABUPATEN KAMPAR
}

Salvi Novita ${ }^{1}$, Manyuk Fauzi ${ }^{2}$, Imam Suprayogi ${ }^{3}$

1,2,3Program Magister Teknik Sipil Fakultas Teknik Universitas Riau

Email: salvinovita@gmail.com (korespondensi)

\begin{abstract}
The development of the territory in an area will cause the water demand increased continually, lined with population growth. The tendency that often go with it, is that the imbalance between availability and demand of water. To achieve a balance of water demand and water availability in the future, studying and surveying the components of water demand and water use efficiency are needed.

The largest water availability for a probability of $80 \%$ for the Kampar watershed is in January with a value of $371.96 \mathrm{m3} / \mathrm{second}$ and for the Siak watershed is in December with a value of $18.06 \mathrm{m3} / \mathrm{second}$ while the smallest water availability is for a probability of $80 \%$ for the watershed. Kampar is in August with a value of $120.19 \mathrm{m3} /$ second and for the Siak River Basin is in July with a value of $5.16 \mathrm{m3} / \mathrm{second}$.

Water demand in Kampar Regency include, among others, Total irrigation water requirements for 22,391,782 m3 in 2017 and 22,388,055 m3 in 2037; domestic water needs 3,889,618 m3 in 2017 and 6,460,267 m3 in 2037, non domestic water needs (1,162,869 m3 in 2017 and 2,250,117 m3 in 2037, industrial water needs 3,690. $267 \mathrm{m3}$ in 2017 and 6,696,326 m3 in 2037, livestock water needs 134,948 $\mathrm{m3}$ in 2017 and 631,511 m3 in 2037, fishery water needs 35,925,023 m3 in 2017 and 44,776,333 m3 in 2037 and water needs plantation 148,253,099 $m 3$ in 2017 and 188,219,394 m3 in 2037.

From the calculation, it is found that service areas that will experience a water deficit in the next 20 years are Tapung Hilir and Kampar Districts. The need for water that dominates the use of surface water in Kampar Regency is the need for irrigation and plantation water.
\end{abstract}

Keywords: availability, requirements, water balance.

\begin{abstract}
Abstrak
Perkembangan wilayah pada suatu daerah akan menyebabkan kebutuhan air terus meningkat seiring dengan laju pertumbuhan penduduk. Kecenderungan yang sering terjadi adalah adanya ketidakseimbangan antara ketersediaan dan kebutuhan air. Untuk mencapai keseimbangan antara kebutuhan air dan ketersediaan air di masa mendatang, diperlukan upaya pengkajian komponen komponen kebutuhan air, serta efisiensi penggunaan air.

Ketersediaan air terbesar untuk probabilitas 80\% untuk DAS Kampar adalah pada bulan Januari dengan nilai sebesar $371,96 \mathrm{m3} /$ detik dan untuk DAS Siak adalah pada bulan Desember dengan nilai sebesar 18,06 m3/detik sedangkan ketersediaan air terkecil untuk probabilitas $80 \%$ untuk DAS Kampar adalah pada bulan Agustus dengan nilai sebesar 120,19 m3/detik dan untuk DAS Siak adalah pada bulan Juli dengan nilai sebesar 5,16 m3/detik. Kebutuhan air pada Kabupaten Kampar yaitu antara lain kebutuhan air irigasi 22.391.782 m3 pada tahun 2017 dan 22.388.055 m3 pada tahun 2037; kebutuhan air penduduk 3.889.618 m3 pada tahun 2017 dan 6.460.267 m3 pada tahun 2037, kebutuhan air perkotaan 162.869 m3 pada tahun 2017 dan 2.250.117 m3 pada tahun 2037, kebutuhan air industri 3.690.267 m3 pada tahun 2017 dan 6.696.326 m3 pada tahun 2037, kebutuhan air peternakan 134.948 m3 pada tahun 2017 dan $631.511 \mathrm{m3}$ pada tahun 2037, kebutuhan air perikanan 35.925.023 m3 pada tahun 2017 dan 44.776 .333 m3 pada tahun 2037 dan kebutuhan air perkebunan 148.253.099 m3 pada tahun 2017 dan 188.219.394 m3 pada tahun 2037.

Dari hasil perhitungan didapat daerah layanan yang mengalami defisit air pada 20 tahun mendatang adalah Kecamatan Tapung Hilir dan Kecamatan Kampar. Kebutuhan air yang mendominasi penggunaan air permukaan di Kabupaten Kampar adalah kebutuhan air irigasi dan perkebunan.
\end{abstract}

Kata kunci: Ketersediaan, Kebutuhan, Neraca Air. 


\section{PENDAhuluan}

Perkembangan wilayah pada suatu daerah akan menyebabkan kebutuhan air terus meningkat seiring dengan laju pertumbuhan penduduk. Pemenuhan kebutuhan pangan dan aktivitas penduduk selalu erat kaitannya dengan kebutuhan akan air. Tuntutan tersebut tidak dapat dihindari, tetapi haruslah diprediksi dan direncanakan pemanfaatan sebaik mungkin. Kecenderungan yang sering terjadi adalah adanya ketidakseimbangan antara ketersediaan dan kebutuhan air. Untuk mencapai keseimbangan antara kebutuhan air dan ketersediaan air di masa mendatang, diperlukan upaya pengkajian komponen komponen kebutuhan air, serta efisiensi penggunaan air.

Kabupaten Kampar merupakan merupakan salah satu Kabupaten yang berada di Provinsi Riau yang memiliki luas wilayah cukup besar dibanding kabupaten lainnya yang ada di Riau. Pesatnya pertumbuhan penduduk akan mengakibatkan bertambahnya kebutuhan air pada kota tersebut. Hal ini akan berpengaruh terhadap bertambahnya aliran permukaan (run off) dan berkurangnya infiltrasi. Jika dibiarkan terus menerus tanpa ada usaha-usaha untuk memperbaiki situasi ini, maka akan mengakibatkan potensi debit air di Sungai Kampar yang terletak di Kabupaten Kampar akan menjadi berkurang akibat kurangnya resapan air.

Sumber daya air juga dapat menimbulkan bencana apabila tidak dikelola dengan baik. Perbandingan debit maksimum dan minimum Sungai Kampar yaitu 1423,00 m3/detik pada saat musim hujan dan 69,46 $\mathrm{m} 3 /$ detik pada saat musim kemarau (BNPB, 2004). Artinya saat musim hujan DAS Kampar akan mengalami luapan aliran air permukaan sehingga berpotensi menyebabkan kebanjiran sementara dan di musim kemarau mengalami kekeringan. Maka tidak salah jika terjadi hujan lebat, sebagian wilayah di Kabupaten Kampar mengalami kebanjiran. Menurut Badan Perencanaan Daerah (Bappeda) Kabupaten Kampar (2004), banjir yang terjadi di Kabupaten Kampar diindikasikan oleh kerusakan badan sungai di wilayah tengah ke hulu serta adanya pertumbuhan pembangunan pada wilayah yang berpotensi sebagai daerah resapan.

Langkah untuk mencegah terjadinya bencana banjir dan kekeringan dapat melalui informasi ketersediaan air. Adanya informasi mengenai kebutuhan dan ketersediaan air digunakan untuk menilai status sumber daya air. Hasil penilaian yang diperoleh dapat membantu perencanaan masa depan dalam pembangunan berkelanjutan. Penelitian ini dilakukan membantu melihat pengembangan sumber daya air dan mengurangi bahaya banjir dan kekeringan yang mungkin terjadi di Kabupaten Kampar.

Kondisi tersebut menunjukkan bahwa pengelolaan air di Kabupaten Kampar buruk. Untuk itu perlu dianalisis, ketersediaan air (debit andalan) di Daerah Aliran Sungai untuk kebutuhan domestik, industri, irigasi, dan peternakan sehingga dapat diketahui perbandingan antara ketersediaan dan kebutuhan air di Kabupaten Kampar. Kemudian diproyeksikan sampai 20 tahun ke depan. Sehingga didapat rasio kebutuhan dan ketersediaan air yang bisa diklasifikasikan di Kabupaten Kampar sampai 20 tahun mendatang

\section{TINJAUAN PUSTAKA}

\subsection{Siklus Hidrologi}

Siklus hidrologi merupakan sirkulasi air yang tidak pernah berhenti. Inti dari proses hidrologi adalah pemanasan dari air laut oleh sinar matahari yang berjalan secara terus menerus. Siklus hidrologi dimulai dari proses peng uapan dari bumi meliputi penguapan di samudera, laut, danau, rawa, sungai maupun bendungan dan beberapa tempat yang ada di permukaan tanah. Air yang ada di bumi akan berubah menjadi uap air karena pemanasan sinar matahari dan kemudian naik ke atmosfer oleh angin. Uap air yang naik ke atmosfer akan mengalami kondensasi yang merupakan proses perubahan uap air menjadi titik-titik air, titik-titik air tersebut akan jatuh ke permukaan laut maupun tanah. Namun, tidak semua titik hujan sampai ke permukaan tanah, titik air yang tertahan pada tumbuh-tumbuhan disebut dengan intersepsi lalu selebihnya sampai ke permukaan tanah. Pada permukaan tanah terjadi tahapan Run off dimana air akan bergerak dari tempat yang tinggi menuju tempat yang rendah mengisi cekungan tanah maupun pergerakan yang terjadi melalui saluran-saluran air misalnya saluran drainase, danau, sungai dan laut. Sebagian dari air akan mengisi pori-pori tanah dan meresap ke dalam tanah (infiltrasi).

\subsection{Evapotranspirasi Metode Penman- Monteith}

Evapotranspirasi merupakan penguapan yang terjadi dari permukaan yang bervegetasi. Evapotranspirasi merupakan gabungan dari peristiwa evaporasi dan transpirasi yang berlangsung secara bersama-sama. Perhitungan evapotranspirasi tanaman acuan menurut metode Penman- 
Monteith memerlukan data iklim. Data iklim tersebut adalah:

1. Suhu udara rata-rata dalam satuan derajat celcius (oC)

2. Kelembaban relatif rata-rata dalam persen (\%)

3. Kecepatan angin rata-rata dalam satuan meter per detik $(\mathrm{m} / \mathrm{dt})$

4. Lama penyinaran matahari dalam satu hari yang dinyatakan dengan satuan jam atau dalam persentase $\mathrm{n} / \mathrm{N}(\%)$.

Pengolahan data cuaca untuk melakukan penghitungan evapotranspirasi tanaman acuan dengan metode Penman-Monteith perlu dilakukan mengingat pencatatan data di lapangan yang berbeda-beda. Menurut SNI 7745-2012, perhitungan evapotranspirasi tanaman acuan dengan metode PenmanMonteith (Monteith, 1965) adalah:

$$
\text { ETo }=\frac{0,408 \Delta R_{n}+Y \frac{900}{(T+273)} U_{2}\left(e_{s}-e_{a}\right)}{\Delta+\gamma\left(1+0,34 U_{2}\right)}
$$

Dengan :

$$
\begin{array}{ll}
E T_{0}= & \text { evapotranspirasi tanaman acuan } \\
& (\mathrm{mm} / \mathrm{hari}) ; \\
R_{n}= & \text { radiasi matahari netto di atas } \\
& \text { permukaan tanaman }\left(\mathrm{MJ} / \mathrm{m}^{2} / \mathrm{hari}\right) ; \\
T= & \text { suhu udara rata-rata }\left({ }^{\circ} \mathrm{C}\right) ; \\
U_{2}= & \text { kecepatan angin pada ketinggian } 2 \\
& \text { m dari atas permukaan tanah, } \\
& (\mathrm{m} / \mathrm{s}) ; \\
= & \text { tekanan uap air jenuh }(\mathrm{kPa}) ; \\
e_{s} \quad & \text { tekanan uap air aktual }(\mathrm{kPa}) ; \\
e_{a}= & \text { kemiringan kurva tekanan uap air } \\
\Delta & \text { terhadap suhu }\left(\mathrm{kPa} /{ }^{\circ} \mathrm{C}\right) ; \\
V= & \text { konstanta psikrometrik }\left(\mathrm{kPa} /{ }^{\circ} \mathrm{C}\right)
\end{array}
$$

\subsection{Ketersediaan Air}

Ketersediaan air dalam pengertian sumberdaya air pada dasarnya berasal dari air hujan (atmosferik), air permukaan dan air tanah. Hujan yang jatuh di atas permukaan pada suatu DAS atau wilayah sungai (WS) sebagian akan menguap kembali sesuai dengan proses iklimnya, sebagian akan mengalir melalui permukaan dan sub permukaan masuk ke dalam saluran, sungai atau danau dan sebagian lagi akan meresap jatuh ke tanah sebagai pengisian kembali (recharge) pada kandungan air tanah yang ada (Pribadi \& Oktavia, 2007).

Analisis ketersediaan air atau analisis potensi air dilakukan dengan metode pendekatan berdasarkan data debit aliran dalam runtut-waktu (time-series) yang ada lebih dari 10 tahun, apabila tidak tersedia data debit maupun data debit kurang dari 5 tahun maka perkiraan potensi sumber daya air dilakukan berdasarkan curah hujan, iklim dan kondisi DAS dengan menggunakan model hujan-aliran (rainfall-runoff model).

\subsection{Analisis Debit Andalan}

Debit andalan adalah debit sungai yang diharapkan selalu ada sepanjang tahun dan dapat dengan membuat terlebih dahulu garis durasi untuk debit-debit yang disamai atau dilampaui, kemudian ditetapkan suatu andalan berupa suatu frekuensi kejadian yang di dalamnya terdapat paling sedikit satu kegagalan. Andalan yang didasarkan atas frekuensi/ probabilitas kejadian dirumuskan sebagai berikut:

$$
P_{1}=\frac{m_{1}}{n_{1}+1} \times 100 \%
$$

Dengan :

$$
\begin{array}{ll}
\mathrm{P}_{1}= & \text { probabilitas terjadinya kumpulan } \\
& \text { nilai yang diharapkan selama } \\
& \text { periode pengamatan } \\
\mathrm{m}_{1}= & \text { nomor urut kejadian, dengan } \\
& \text { urutan variasi dari besar ke kecil. } \\
\mathrm{n}_{1}= & \text { jumlah data }
\end{array}
$$

\subsection{Kebutuhan Air Irigasi}

Perhitungan kebutuhan air irigasi pada umumnya digunakan dengan merujuk pada standar perhitungan Dirjen Pengairan (KP01). Kebutuhan air irigasi merupakan jumlah volume air yang diperlukan untuk memenuhi kebutuhan evaporasi, kehilangan air, kebutuhan air untuk tanaman dengan memperhatikan jumlah air yang diberikan oleh alam melalui hujan dan konstribusi air tanah. Menurut (Sukmanda, 2016).

Besarnya kebutuhan air irigasi bergantung pada cara pengolahan Iahan (Priyonugroho, 2014), perkolasi, curah hujan efektif, luas daerah irigasi, pola dan jadwal tanam, sistem golongan dan efisiensi saluran irigasi.

\subsubsection{Penyiapan lahan}

Kebutuhan air untuk penyiapan lahan umumnya menentukan kebutuhan maksimum air irigasi pada suatu proyek irigasi. Faktor-faktor penting yang menentukan besarnya kebutuhan air untuk penyiapan lahan adalah:

a. Lamanya waktu yang dibutuhkan untuk menyelesaikan pekerjaan penyiapan lahan.

Waktu yang diperlukan untuk penyiapan lahan tergantung pada kondisi lapangan, biasanya antara 30 - 45 hari. Pada penelitian ini diambil jangka waktu penyiapan Iahan 30 hari. 
b. Jumlah air yang diperlukan untuk penyiapan lahan

Metode yang dikembangkan oleh Van de Goor dan Ziljstar (1986), perhitungan irigasi selama perhitungan lahan didasarkan pada laju air yang konstan dalam liter/detik selama periode penyiapan lahan dan diperoleh rumus sebagai berikut.

$$
\begin{aligned}
I R & =\frac{M \times e^{k}}{e^{k}-1} \\
M & =E_{0}+P \\
k & =M \times \frac{T}{S}
\end{aligned}
$$

Dengan :

$I R=$ kebutuhan air pengolahan tanah (mm/hari)

$M=$ kebutuhan air untuk mengganti atau mengkompensi kehilangan air akibat evaporasi dan perkolasi di daerah yang sudah dijenuhkan ( $\mathrm{mm} /$ hari),

$E_{O}=$ evaporasi air terbuka yang diambil 1,1 dari Eto selama penyiapan lahan ( $\mathrm{mm} /$ hari),

$P=$ perkolasi,

$T=$ jangka waktu penyiapan lahan (hari),

$S=$ kebutuhan air yang diperlukan untuk penjenuhan ditambah dengan lapisan air, yakni $250+50=300 \mathrm{~mm}$,

$e=$ eksponensial.

Untuk penjenuhan dan pengolahan lahan diperlukan lapisan air setebal $250 \mathrm{~mm}$ dan ditambah $50 \mathrm{~mm}$ lapisan air awal setelah selesai, secara keseluruhan lapisan air yang diperlukan menjadi $300 \mathrm{~mm}$. Bila lahan dibiarkan selama jangka waktu yang lama (2,5 bulan atau lebih) maka lapisan air yang diperlukan untuk penyiapan lahan adalah setebal $300 \mathrm{~mm}$.

Menurut Kriteria Perencanaan Irigasi 01 (1986), kebutuhan air irigasi selama penyiapan lahan yang dhitung menurut rumus di atas dapat dilihat pada Tabel 1 berikut ini.

Tabel 1. Kebutuhan Air untuk Penyiapan Lahan

\begin{tabular}{|ccccc|}
\hline \multirow{2}{*}{$\mathrm{E}_{0}+\mathrm{P}$} & \multicolumn{2}{c}{$\mathrm{T}=30$ hari } & \multicolumn{2}{c|}{$\mathrm{T}=45$ hari } \\
\cline { 2 - 5 }$(\mathrm{mm} / \mathrm{hari})$ & $\begin{array}{c}\mathrm{S}=250 \\
(\mathrm{~mm})\end{array}$ & $\begin{array}{c}\mathrm{S}=300 \\
(\mathrm{~mm})\end{array}$ & $\begin{array}{c}\mathrm{S}=250 \\
(\mathrm{~mm})\end{array}$ & $\begin{array}{c}\mathrm{S}=300 \\
(\mathrm{~mm})\end{array}$ \\
\hline 5,0 & 11,1 & 12,7 & 8,4 & 9,5 \\
5,5 & 11,4 & 13,0 & 8,8 & 9,8 \\
6,0 & 11,7 & 13,3 & 9,1 & 10,1 \\
6,5 & 12,3 & 13,6 & 9,4 & 10,4 \\
7,0 & 12,6 & 13,9 & 9,8 & 10,8 \\
7,5 & 13,0 & 14,5 & 10,1 & 11,4 \\
8,0 & 13,3 & 14,8 & 10,5 & 11,8 \\
9,0 & 14,0 & 15,5 & 11,2 & 12,5 \\
9,5 & 14,3 & 15,8 & 11,6 & 12,9 \\
10,0 & 14,3 & 16,2 & 12,0 & 12,9 \\
10,5 & 14,7 & 16,2 & 12,4 & 13,2 \\
11,0 & 15,0 & 16,5 & 12,8 & 13,6 \\
\hline
\end{tabular}

Sumber : Standar Perencanaan Irigasi KP-01

\subsubsection{Penggunaan konsumtif}

Penggunaan konsumtif adalah jumlah air yang digunakan oleh tanaman untuk proses evapotranspirasi, yang besarnya dipengaruhi oleh jenis tanaman, umur tanaman dan faktor klimatologi. Adapun penggunaan konsumtif dapat dihitung dengan persamaan:

Dengan :

$$
E T_{c}=K c \times E T_{O}
$$

$E T_{C} \quad=$ penggunaan konsumtif $(\mathrm{mm} /$ hari $)$

\begin{tabular}{|c|c|c|c|c|c|}
\hline \multirow{2}{*}{$\begin{array}{l}\text { Periode } \\
\text { tengah } \\
\text { bulanan }\end{array}$} & \multicolumn{2}{|c|}{ Padi Medeco/Prosida } & \multicolumn{2}{|c|}{$\overline{F A O}$} & \multirow[b]{2}{*}{ Kedelai } \\
\hline & $\begin{array}{c}\text { Varietas } \\
\text { biasa }\end{array}$ & $\begin{array}{l}\text { Varietas } \\
\text { unggul }\end{array}$ & $\begin{array}{c}\text { Varietas } \\
\text { biasa }\end{array}$ & $\begin{array}{l}\text { Varietas } \\
\text { unggul }\end{array}$ & \\
\hline 1 & 1,20 & 1,20 & 1,10 & 1,10 & 0,50 \\
\hline 2 & 1,20 & 1,27 & 1,10 & 1,10 & 0,75 \\
\hline 3 & 1,32 & 1,33 & 1,10 & 1,05 & 1,00 \\
\hline 4 & 1,40 & 1,30 & 1,10 & 1,05 & 1,00 \\
\hline 5 & 1,35 & 1,30 & 1,10 & 0,95 & 0,82 \\
\hline 6 & 1,24 & 0,00 & 1,05 & 0,00 & 0,45 \\
\hline 7 & 1,12 & & 0,95 & & \\
\hline
\end{tabular}

$K C=$ koefisien tanaman

$E T_{O}=$ evapotranspirasi potensial $(\mathrm{mm})$

Tabel 2. Harga Koefisien Tanaman

Sumber : Standar Perencanaan Irigasi KP-01

\subsubsection{Perkolasi}

Perkolasi adalah gerakan air ke bawah dari zona tidak jenuh yang terletak di antara permukaan sampai ke permukaan air tanah (zona jenuh). Laju perkolasi dapat mencapai 1-3 mm/hari. Pada penelitian ini laju perkolasi yang dipakai adalah $3 \mathrm{~mm} /$ hari.

\subsubsection{Penggantian lapisan air (WLR)}

Menurut Kriteria Perencanaan 01 Irigasi, setelah pemupukan dilakukan penjadwalan dan melakukan penggantian lapisan air sesuai kebutuhan. Apabila tidak ada penjadwalan maka dilakukan penggantian sebanyak dua kali, masingmasing $50 \mathrm{~mm}$ (atau 3,3 $\mathrm{mm} /$ hari) selama sebulan dan dua bulan setelah transplantasi.

\subsubsection{Curah hujan efektif (Reff)}

Curah hujan efektif ( $R_{\text {eff }}$ ) ditentukan berdasarkan besarnya $R_{80}$ yang merupakan curah hujan yang besarnya dapat dilampaui sebanyak $80 \%$ atau dengan kata lain dilampauinya 8 kali kejadian dari 10 kali kejadian. Artinya, bahwa besarnya curah hujan yang terjadi lebih kecil dari $R_{80}$ mempunyai kemungkinan hanya $20 \%$ (Sukmanda, 2016).

Menghitung curah hujan efektif untuk tanaman padi digunakan persamaan sebagai berikut:

$$
R_{\text {eff }}=\frac{1}{15} \times R
$$

\subsubsection{Kebutuhan air di sawah}

Perkiraan banyaknya air untuk irigasi. Kebutuhan air di sawah untuk tanaman padi dihitung dengan persamaan berikut: 


$$
N F R=E T_{C}+P+W L R-R_{\text {eff }}
$$

Dengan :

$N F R=$ kebutuhan air di sawah $(\mathrm{mm} /$ hari $)$

$E T_{C}=$ penggunaan konsumtif $(\mathrm{mm} /$ hari)

$P \quad=$ perkolasi ( $\mathrm{mm} /$ hari)

$W L R=$ penggantian lapisan air

$R_{\text {eff }}=$ curah hujan efektif ( $\mathrm{mm} /$ hari)

\subsection{Kebutuhan Air Domestik}

Faktor utama dalam menentukan kebutuhan air domestik adalah dengan mengetahui jumlah dan pertumbuhan penduduk. Berikut persamaan yang digunakan untuk meghitung kebutuhan air domestik.

$$
\mathrm{Q}_{(\mathrm{p}) i}=\mathrm{N}_{(\mathrm{p})} \times \mathrm{q} \times \mathrm{n} \times \mathrm{f}
$$

Dengan :

$$
\begin{array}{ll}
\mathrm{Q}_{(\mathrm{p}) \mathrm{i}}= & \text { kebutuhan air domestik }\left(\mathrm{m}^{3}\right) \text { pada } \\
& \text { bulan ke-i } \\
\mathrm{N}_{(\mathrm{p})}= & \text { jumlah penduduk } \\
\mathrm{q}= & \text { kebutuhan air penduduk } \\
& (\mathrm{l} / \mathrm{jiwa} / \mathrm{h} \text { ari }) \\
\mathrm{n}= & \text { jumlah hari dalam } 1 \text { bulan } \\
\mathrm{f} \quad= & \text { faktor konversi }
\end{array}
$$

Berdasarkan jenis kota dan jumlah penduduk dari suatu daerah tersebut maka dapat ditentukan standar kebutuhan air dan kriteria perencanaan air bersih yang dapat dilihat pada Tabel 3 berikut.

Tabel 3 Kebutuhan air bersih rumah tangga per orang per hari menurut kategori kota

\begin{tabular}{|ccc|}
\hline Kategori kota & $\begin{array}{c}\text { Jumlah Penduduk } \\
\text { (jiwa) }\end{array}$ & $\begin{array}{c}\text { Komsumsi air } \\
\text { (liter/jiwa/hari) }\end{array}$ \\
\hline Semi urban (V) & $3.000-20.000$ & $60-90$ \\
Kota kecil (IV) & $20.000-100.000$ & $90-110$ \\
Kota sedang (III) & $100.000-500.000$ & $100-125$ \\
Kota besar (II) & $500.000-1.000 .000$ & $120-150$ \\
Metropolitan (I) & $>1.000 .000$ & $150-200$ \\
\hline
\end{tabular}

Sumber : SNI 6728.1:2015

\subsection{Kebutuhan \\ Air Perkotaan \\ (Komersial Dan Sosial) - Non Domestik}

Kebutuhan air perkotaan, yaitu untuk komersial dan sosial seperti toko, gudang, bengkel, sekolah, rumah sakit, hotel, dan sebagainya diasumsikan antara $15 \%$ sampai dengan $30 \%$ dari total air pemakaian air bersih rumah tangga.

\subsection{Kebutuhan Air Industri}

Perusahaan industri pengolahan dibagi dalam 4 (empat) golongan yaitu sebagai berikut.
Tabel 4 Penggolangan Perusahaan Industri

\begin{tabular}{|cc|}
\hline Golongan Industri & Banyak Tenaga Kerja \\
\hline Besar & 100 orang atau lebih \\
Sedang & $20-99$ orang \\
Kecil & $5-19$ orang \\
Rumah tangga & $1-4$ orang \\
\hline
\end{tabular}

Sumber: Badan Pusat Statistik Kabupaten Kampar.

Persamaan kebutuhan air industri.

$$
\mathrm{Q}_{(\text {ind })}=\mathrm{N}_{(\text {ind })} \times \mathrm{q} \times \mathrm{n} \times \mathrm{f}
$$

Dengan :

$\mathrm{Q}_{\text {(ind) }}=$ kebutuhan air industri (I/hari)

$\mathrm{N}_{\text {(ind) }}=$ jumlah industri

$\mathrm{q}=$ kebutuhan air (I/unit/hari)

$\mathrm{n}=$ jumlah hari dalam 1 bulan

$\mathrm{f} \quad=$ faktor konversi

\subsection{Kebutuhan Air Peternakan}

Kebutuhan air untuk jenis ternak dapat dilihat pada Tabel 5 .

Tabel 5 Unit Kebutuhan Air untuk Ternak

\begin{tabular}{cc}
\hline Jenis Ternak (ekor) & $\begin{array}{c}\text { Unit Kebutuhan Air } \\
\text { (liter/ekor/hari) }\end{array}$ \\
\hline Sapi/kerbau & 40 \\
Kambing/domba & 5 \\
Babi & 6 \\
Unggas & 0,6
\end{tabular}

Sumber : SNI 6728.1:2015

Berikut adalah rumus yang digunakan untuk menghitung kebutuhan air untuk peternakan.

$$
\mathrm{Q}_{\mathrm{E}}=\left(\mathrm{q}_{(1)} \times \mathrm{P}_{(1)}+\mathrm{q}_{(2)} \times \mathrm{P}_{(2)}+\mathrm{q}_{(3)} \times \mathrm{P}_{(3)}\right)
$$

Dengan :

$\mathrm{Q}_{\mathrm{E}}=$ kebutuhan air untuk ternak (I/hari)

$\mathrm{q}_{(1)}=$ kebutuhan air untuk sapi, kerbau, dan kuda (l/ekor/hari)

$\mathrm{q}_{(2)}=$ kebutuhan air untuk kambing dan domba (l/ekor/hari)

$\mathrm{q}_{(3)}=$ kebutuhan air untuk unggas (l/ekor/hari)

$P_{(1)}=$ jumlah sapi, kerbau, dan kuda (ekor)

$P_{(2)}=$ jumlah kambing dan domba (ekor)

$P_{(3)}=$ jumlah ungags (ekor)

\subsection{Kebutuhan Air Perikanan}

Kebutuhan air untuk perikanan diperkirakan berdasarkan luas kolam, tipe kolam serta kedalaman air yang diperlukan. Kebutuhan ini meliputi kebutuhan untuk mengisi kolam pada saat awal tanam dan penggantian air. Debit air yang baik untuk kolam tidak kurang dari $10-15 \mathrm{lt} / \mathrm{dt} / \mathrm{ha}$. Kebutuhan air untuk perikanan untuk selanjutnya dapat di hitung dengan menggunakan rumus sebagai berikut :.

$$
\mathrm{Q}_{f p}=\frac{q_{f p}}{1000} \times \mathrm{A}_{\mathrm{fp}} \times 10000
$$

Dengan :

$$
\begin{aligned}
& \mathrm{Q}_{\mathrm{fp}}= \begin{array}{l}
\text { kebutuhan } \\
\text { (m3/hari) }
\end{array} \text { air untuk perikanan } \\
& \mathrm{q}_{(\mathrm{fp})}=\begin{array}{l}
\text { kebutuhan } \\
(\mathrm{I} / \text { hari/ha) }
\end{array} \text { air untuk pembilasan }
\end{aligned}
$$


$A_{f p}=$ luas kolam ikan (ha)

\subsection{Kebutuhan Air Perkebunan}

Kebutuhan air untuk beberapa tanaman lainnya dapat dilihat pada Tabel 6 sebagai berikut:

Tabel 6 Unit Kebutuhan Air untuk Tanaman

\begin{tabular}{|cccc|}
\hline Tanaman & Km/hari & $\begin{array}{c}\text { Kebutuhan Air } \\
\mathrm{mm} / \text { Bulan }\end{array}$ & $\mathrm{mm} /$ Tahun \\
\hline Kepalapa Sawit & $4.10-4.65$ & $123-139.5$ & $1476-1674$ \\
Kakao & $2.22-3.33$ & $66.6-99.9$ & $800-1200$ \\
Kopi & $2.22-3.34$ & $66.6-99.9$ & $800-1200$ \\
Deciduous trees & $1.94-2.91$ & $58.2-87.3$ & $700-1050$ \\
Tebu & $2.77-4.16$ & $83.1-124.8$ & $600-1500$ \\
Alfalfa & $1.66-4.16$ & $49.8-124.8$ & $650-1000$ \\
Alpukat & $1.80-2.77$ & $54-83.1$ & $650-1000$ \\
Pisang & $1.94-4.72$ & $58.2-141.6$ & $700-1700$ \\
Padi & $4.16-7.91$ & $124-237.3$ & $1500-2850$ \\
Jagung & $3.33-6.25$ & $99.9-188.7$ & $1200-2250$ \\
Kedelai & $3.75-6.87$ & $112.5-206.1$ & $1350-2475$ \\
\hline
\end{tabular}

\subsection{Analisis Neraca Air dan Status Rasio Sumber Daya Air}

Siklus hidrologi merupakan hubungan antara aliran inflow dan outflow di suatu daerah untuk suatu perioda tertentu disebut neraca air atau keseimbangan air (water balance). Analisis neraca air (water balance) adalah suatu analisa yang menggambarkan pemanfaatan sumber daya air suatu daerah tinjauan yang didasarkan pada perbandingan antara kebutuhan dan ketersediaan air.

Secara umum analisis perhitungan neraca air dapat dilihat pada persamaan berikut:

\section{Neraca air = ketersediaan - kebutuhan}

Jika dari perhitungan diperoleh nilai positif, maka menandakan terdapat kelebihan air atau surplus. Namun sebaliknya jika terjadi nilai negatif, maka daerah tempat penelitian terdapat kekurangan air atau deficit.

Hubungan antara ketersediaan air dan kebutuhan air dijabarkan dalam neraca air untuk dilakukan penilaian. Penilaian dilakukan menggunakan batasan status rasio (SR) untuk mengetahui mengetahui status sumber daya air (WRS). Terdapat empat klasifikasi status sumber daya air, yaitu pada Tabel 7.

Tabel 7 Ambang Batas Cekaman Air

\begin{tabular}{ccc}
\hline Klasifikasi & $\begin{array}{c}\text { Indeks pemakaian air }= \\
\text { Kebutuhan air/ ketersediaan } \\
\text { air }\end{array}$ & $\begin{array}{c}\text { Simbol } \\
\text { warna }\end{array}$ \\
\hline I & $>0.4$ & Merah \\
II & 0.2 to 0.4 & Kuning \\
III & 0.1 to 0.2 & Hijau \\
IV & $<0.1$ & Biru \\
\hline
\end{tabular}

Sumber : SNI 6728.1:2015

\section{METODOLOGI PENELITIAN}

\subsection{Lokasi Penelitian}

Lokasi penelitian tugas akhir in dilakukan di Kabupaten Kampar, Provinsi Riau. Kabupaten Kampar memiliki luas lebih kurang 1.128.928 Ha, yang terletak antara $01^{\circ} 00^{\prime} 40^{\prime \prime}$ lintang utara sampai $00^{\circ} 27^{\prime} 00^{\prime \prime}$ lintang selatan dan $100^{\circ} 28^{\prime} 30^{\prime \prime}$ - 101 ${ }^{\circ} 14^{\prime} 30^{\prime \prime}$ bujur timur. Kabupaten Kampar memiliki 21 kecamatan, 8 kelurahan dan 242 desa.

Berdasarkan satuan wilayah sungai (SWS), Kabupaten Kampar terbagi atas dua satuan wilayah sungai, yaitu SWS Kampar dan SWS Siak. Sungai besar diantaranya Sungai Kampar yang panjangnya $\pm 413,5 \mathrm{~km}$ dengan kedalaman rata-rata 7,7 m dan lebar rata-rata 143 meter. Sungai Kampar mengalir dari hulu di punggung Bukit Barisan kearah Timur membelah wilayah Kabupaten Kampar. Sungai Kampar Kanan melalui beberapa kecamatan diantaranya kecamatan Koto Kampar Hulu, XIII Koto Kampar, Kuok, Salo, Bangkinang, Kampar, Kampar Timur, Kampar Utara, Rumbio Jaya, Tambang, Siak Hulu. Kemudian ada sungai Kampar Kiri melalui kecamatan Kampar Kiri, Gunung Sahilan, Kampar Kiri Tengah, Kampar Kiri Hilir.

Selanjutnya ada Sungai Siak yang bagian hulu ada di wilayah Kabupaten Kampar. Panjang sungai Siak yakni $\pm 90 \mathrm{~km}$ dengan kedalaman rata-rata $8-12 \mathrm{~m}$ yang melintasi kecamatan Tapung.

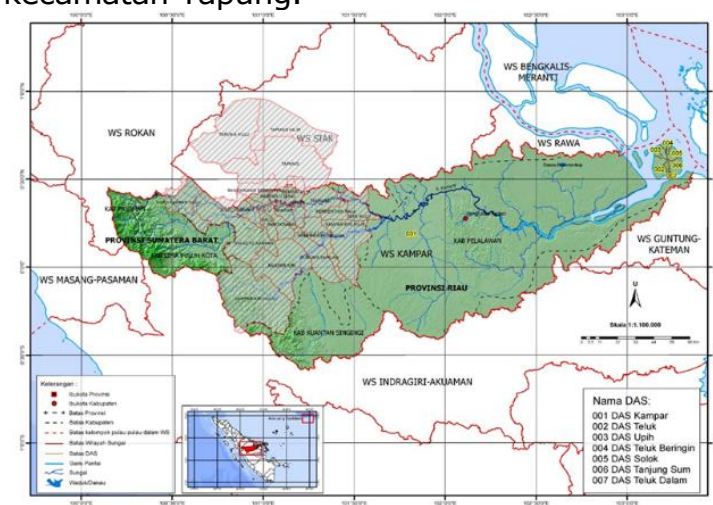

Gambar 1 Lokasi Penelitian

\subsection{Pengumpulan Data}

Data yang dibutuhkan dalam penelitian ini berupa data sekunder yang diperoleh dari Badan Pusat Statistik Kabupaten Kampar dan Badan Wilayah Sungai Sumatera III. Adapun data-data yang dikumpulkan adalah sebagai berikut.
1. Domestik (populasi penduduk)
2. Non domestik (industri dan ternak)
3. Irigasi
4. Perkebunan
5. Perikanan
6. Curah hujan
7. Debit sungai 


\section{Klimatolog}

\subsection{Tahap Perhitungan}

Tahapan - tahapan kajian disajikan pada Gambar 3, secara rinci dapat diuraikan sebagai berikut:

1. Pengumpulan data-data yang telah dilakukan.

2. Menghitung kebutuhan air total yaitu: rumah tangga, non domestik, industri, irigasi, perkebunan dan perikanan untuk masing - masing kecamatan di wilayah Kabupaten Kampar.

3. Menentukan besarnya ketersediaan air atau debit andalan pada DAS Kampar dan DAS Siak, digunakan metode Analisis Regional. Data yang menjadi parameter dalam menetukan debit andalan adalah data debit pos duga air, luas daerah pos duga air dan luas kecamatan.

4. Menghitung besarnya evapotranspirasi dibutuhkan data-data klimatologi yang meliputi temperatur udara, kecepatan angina, kelembaban udara, dan lama penyinaran matahari. Nilai ETo dihitung dengan menggunakan metode PenmannMounteith

5. Proyeksi Total Kebutuhan dan Ketersediaan Air. Pada penelitian ini, dilakukan terlebih dahulu perhitungan kebutuhan dan ketersediaan air dengan metode yang sudah dijelaskan dan dipilih berdasarkan debit Q80\%. Setelah itu dilakukan proyeksi hingga tahun 2037.

6. Analisis neraca air dilakukan dengan mencari selisih antara hasil analisis ketersediaan air dan analisis kebutuhan air untuk kondisi 20 tahun ke depan dengan membandingkan dengan kondisi yang ada pada saat ini. Ketersediaan yang digunakan adalah ketersediaan air berdasarkan perhitungan debit andalan $80 \%$.

\section{HASIL DAN PEMBAHASAN}

\subsection{Analisis Ketersediaan Air}

Ketersediaan air dihitung berdasarkan metode analisis Regional yang diperoleh dari data debit sungai dan luas daerah pos duga air. Debit andalan yang digunakan pada penelitian ini dihitung berdasarkan debit perhitungan dengan Metode analisis Regional dan dihitung berdasarkan perhitungan $80 \%$, kejadian dari masing-masing data debit diurutkan terlebih dahulu dari yang terbesar ke debit yang terkecil. Hasil perhitungan debit andalan disajikan pada Tabel 8 (terlampir).

Dari hasil perhitungan dapat dilihat bahwa debit andalan terbesar terdapat pada Kecamatan Kampar Kiri Hulu yang juga mempunyai luas wilayah terbesar di Kabupaten Kampar.

\subsection{Kebutuhan Irigasi}

Kebutuhan air irigasi rata-rata pertahun untuk semua wilayah kecamatan di Kabupaten Kampar dapat dilihat pada Tabel 9 Berdasarkan Tabel 9 dapat dilihat bahwa kebutuhan air domestik yang terbesar yaitu di Kecamatan Tambang karena memiliki luas lahan irigasi yang paling besar yaitu seluas 2438,66 hektar.

Tabel 9 Proyeksi Volume Kebutuhan Air Irigasi Rata-rata Pertahun (m3)

\begin{tabular}{|c|c|c|c|c|c|}
\hline Tahun & 2017 & 2022 & 2027 & 2032 & 2037 \\
\hline Kampar Kiri & 331.177 & 331.177 & 331.177 & 331.177 & 331.177 \\
\hline Kampar Kiri Hulu & - & & & - & \\
\hline Kampar Kiri Hilir & 55.196 & 55.196 & 55.196 & 55.196 & 55.196 \\
\hline Gunung Sahilan & - & - & - & - & - \\
\hline Kampar Kiri Tengah & - & - & - & - & \\
\hline XIII Koto Kampar & 137.991 & 137.991 & 137.991 & 137.991 & 137.991 \\
\hline Koto Kampar Hulu & 598.879 & 598.879 & 598.879 & 598.879 & 598.879 \\
\hline Kuok & 2.438 .983 & 2.438 .983 & 2.438 .983 & 2.438 .983 & 2.438.983 \\
\hline Salo & 246.375 & 239.260 & 239.108 & 240.294 & 242.648 \\
\hline Tapung & 206.986 & 206.986 & 206.986 & 206.986 & 206.986 \\
\hline Tapung Hulu & 38.637 & 38.637 & 38.637 & 38.637 & 38.637 \\
\hline Tapung Hilir & - & & - & - & 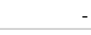 \\
\hline Bangkinang Kota & - & - & - & - & - \\
\hline Bangkinang Seberang & 1.528 .936 & 1.528 .936 & 1.528 .936 & 1.528 .936 & 1.528 .936 \\
\hline Kampar & 4.515 .052 & 4.515 .052 & 4.515.052 & 4.515.052 & 4.515.052 \\
\hline Kampa & 2.050 .540 & 2.050 .540 & 2.050 .540 & 2.050 .540 & 2.050 .540 \\
\hline Rumbio Jaya & 977.902 & 977.902 & 977.902 & 977.902 & 977.902 \\
\hline Kampar Utara & 2.369 .298 & 2.369 .298 & 2.369 .298 & 2.369 .298 & 2.369.298 \\
\hline Tambang & 6.730 .242 & 6.730 .242 & 6.730 .242 & 6.730 .242 & 6.730 .242 \\
\hline Siak Hulu & 165.589 & 165.589 & 165.589 & 165.589 & 165.589 \\
\hline Perhentian & - & - & - & - & \\
\hline
\end{tabular}

\subsection{Kebutuhan Air Domestik}

Data jumlah penduduk yang diperoleh adalah tahun 2012 hingga 2017 yang diperoleh dari Badan Pusat Statistik Kabupaten Kampar. Pada penelitian ini, jumlah penduduk perlu diproyeksi hingga tahun 2037 agar dapat dihitung kebutuhan air hingga tahun 2037. Data yang diperoleh dianalisa terlebih dahulu secara statistik, sehingga nanti diperoleh persamaan sistematis yang mewakili lokasi studi.

Kebutuhan air domestik rata-rata pertahun untuk semua wilayah kecamatan di Kabupaten Kampar dapat dilihat pada Tabel 10

Berdasarkan Tabel 10 dapat dilihat bahwa kebutuhan air domestik yang terbesar yaitu di Kecamatan Siak Hulu yang juga mempunyai jumlah penduduk terbesar dan kebutuhan air domestic terkecil terdapat di Kecamatan Kampar Kiri Hilir.

\subsection{Kebutuhan Air Perkotaan}

Dalam perencanaan studi kebutuhan air Indonesia untuk perkotaan diasumsi sebesar 30 
\% dari kebutuhan air bersih rumah tangga, dengan nilai konstan dari setiap tahapan perencanaan, sehingga sampai proyeksi kebutuhan air untuk tahun 2029 nilainya sama sebesar $30 \%$.

Kebutuhan air perkotaan (non domestic) ratarata pertahun untuk semua wilayah kecamatan di Kabupaten Kampar dapat dilihat pada Tabel 12. Berdasarkan Tabel 11. dapat dilihat bahwa kebutuhan air non domestic yang terbesar yaitu di Kecamatan Siak Hulu dan kebutuhan air non domestic terkecil terdapat di Kecamatan Kampar Kiri Hilir.

Tabel 10 Proyeksi Volume Kebutuhan Air Domestik Rata-Rata Pertahun $\left(\mathrm{m}^{3}\right)$

\begin{tabular}{|c|c|c|c|c|c|}
\hline Tahun & 2017 & 2022 & 2027 & 2032 & 2037 \\
\hline Kampar Kiri & 146.050 & 161.202 & 176.354 & 191.506 & 206.658 \\
\hline Kampar Kiri Hulu & 57.100 & 61.516 & 65.933 & 70.349 & 74.766 \\
\hline Kampar Kiri Hilir & 55.457 & 60.494 & 65.531 & 70.568 & 75.605 \\
\hline Gunung Sahilan & 99.691 & 118.832 & 137.342 & 155.852 & 174.362 \\
\hline Kampar Kiri Tengah & 131.049 & 173.531 & 209.884 & 246.237 & 282.589 \\
\hline XIII Koto Kampar & 117.192 & 129.785 & 143.730 & 159.175 & 176.278 \\
\hline Koto Kampar Hulu & 91.807 & 101.380 & 111.953 & 123.627 & 136.520 \\
\hline Kuok & 122.070 & 134.748 & 148.742 & 164.191 & 181.243 \\
\hline Salo & 125.911 & 139.288 & 154.085 & 170.454 & 188.563 \\
\hline Tapung & 470.814 & 539.285 & 617.713 & 707.548 & 810.448 \\
\hline Tapung Hulu & 410.456 & 485.275 & 573.732 & 678.313 & 801.958 \\
\hline Tapung Hilir & 294.592 & 333.168 & 376.796 & 426.138 & 481.940 \\
\hline Bangkinang Kota & 192.966 & 216.022 & 241.833 & 270.727 & 303.074 \\
\hline Bangkinang Seberang & 159.893 & 175.880 & 193.466 & 212.810 & 234.088 \\
\hline Kampar & 244.436 & 268.397 & 294.707 & 323.597 & 355.318 \\
\hline Kampa & 120.058 & 135.391 & 152.682 & 172.181 & 194.171 \\
\hline Rumbio Jaya & 83.006 & 90.847 & 99.430 & 108.824 & 119.105 \\
\hline Kampar Utara & 83.526 & 92.105 & 101.565 & 111.997 & 123.501 \\
\hline Tambang & 300.605 & 343.541 & 392.610 & 448.687 & 512.774 \\
\hline Siak Hulu & 497.043 & 575.637 & 666.659 & 772.072 & 894.155 \\
\hline Perhentian Raja & 85.898 & 95.846 & 106.946 & 119.332 & 133.151 \\
\hline Jumlah & 3.889 .618 & 4.432.171 & 5.031 .694 & 5.704 .186 & 6.460 .267 \\
\hline $\operatorname{Max}$ & 497.043 & 575.637 & 666.659 & 772.072 & 894.155 \\
\hline Min & 55.457 & 60.494 & 65.531 & 70.349 & 74.766 \\
\hline
\end{tabular}

\subsection{Kebutuhan Industri}

Kebutuhan air industri rata-rata pertahun untuk semua wilayah kecamatan di Kabupaten Kampar dapat dilihat pada Tabel 13. Berdasarkan Tabel 12 dapat dilihat bahwa kebutuhan air non industri yang terbesar yaitu di Kecamatan Siak Hulu dan kebutuhan air non domestic terkecil terdapat di Kecamatan Gunung Sahilan.

\subsection{Kebutuhan Peternakan}

Kebutuhan air peternakan pada lokasi penelitian dihitungan dengan mengalikan jumlah ternak yang sejenis dengan kebutuhan air yang sesuai dengan Tabel 13

Kemudian untuk menentukan metode apa yang digunakan untuk proyeksi adalah dengan mencari standar deviasi terkecil dan koefisien korelasi terbesar dari masingmasing metode.

Selanjutnya perhitungan proyeksi untuk kebutuhan ternak dapat dilihat pada
Tabel 14. Berdasarkan Tabel 14 dapat dilihat bahwa kebutuhan air non industri yang terbesar yaitu di Kecamatan Gunung Sahilan dan Tapung Hilir dan kebutuhan air untuk Peternakan yang terkecil terdapat di Kecamatan Bangkinang Kota.

Tabel 11 Proyeksi Volume Kebutuhan Air Perkotaan Rata-rata Pertahun $\left(\mathrm{m}^{3}\right)$

\begin{tabular}{|c|c|c|c|c|c|}
\hline Tahun & 2017 & 2022 & 2027 & 2032 & 2037 \\
\hline Kampar Kiri & 43.815 & 48.361 & 52.906 & 57.452 & 61.998 \\
\hline Kampar Kiri Hulu & 17.130 & 18.455 & 19.780 & 21.105 & 22.430 \\
\hline Kampar Kiri Hilir & 16.637 & 18.148 & 19.659 & 21.170 & 22.682 \\
\hline Gunung Sahilan & 29.907 & 35.815 & 41.722 & 47.630 & 53.537 \\
\hline Kampar Kiri Tengah & 39.315 & 52.924 & 66.534 & 80.143 & 93.753 \\
\hline XIII Koto Kampar & 35.158 & 38.569 & 41.980 & 45.390 & 48.801 \\
\hline Koto Kampar Hulu & 27.542 & 30.143 & 32.743 & 35.344 & 37.944 \\
\hline Kuok & 36.621 & 40.066 & 43.511 & 46.956 & 50.401 \\
\hline Salo & 37.773 & 41.401 & 45.028 & 48.655 & 52.282 \\
\hline Tapung & 141.244 & 159.176 & 177.108 & 195.040 & 212.972 \\
\hline Tapung Hulu & 123.137 & 142.116 & 161.095 & 180.074 & 199.053 \\
\hline Tapung Hilir & 88.377 & 98.610 & 108.843 & 119.076 & 129.309 \\
\hline Bangkinang Kota & 57.890 & 64.067 & 70.244 & 76.421 & 82.599 \\
\hline Bangkinang Seberang & 47.968 & 52.327 & 56.687 & 61.046 & 65.406 \\
\hline Kampar & 73.331 & 79.876 & 86.422 & 92.967 & 99.512 \\
\hline Kampa & 36.017 & 40.096 & 44.175 & 48.254 & 52.333 \\
\hline Rumbio Jaya & 24.902 & 27.051 & 29.200 & 31.348 & 33.497 \\
\hline Kampar Utara & 25.058 & 27.391 & 29.725 & 32.059 & 34.393 \\
\hline Tambang & 90.181 & 101.452 & 112.722 & 123.992 & 135.263 \\
\hline Siak Hulu & 145.097 & 290.194 & 435.291 & 580.388 & 725.485 \\
\hline Perhentian Raja & 9 & 14 & 9 & 33.793 & 36.468 \\
\hline Jumlah & 1.162 .869 & 1.434 .681 & 1.706 .493 & 1.978 .305 & 2.250 .117 \\
\hline $\operatorname{Max}$ & 145.097 & 290.194 & 435.291 & 580.388 & 725.485 \\
\hline Min & 16.637 & 18.148 & 19.659 & 21.105 & 22.430 \\
\hline
\end{tabular}

Tabel 12 Proyeksi Volume Kebutuhan Air Industri Rata-rata Pertahun $\left(\mathrm{m}^{3}\right)$

\begin{tabular}{|c|c|c|c|c|c|}
\hline Tahun & 2017 & 2022 & 2027 & 2032 & 2037 \\
\hline Kampar Kiri & 142.958 & 158.167 & 173.375 & 188.583 & 203.792 \\
\hline Kampar Kiri Hulu & 19.771 & 24.333 & 28.896 & 33.458 & 38.021 \\
\hline Kampar Kiri Hilir & 53.229 & 76.549 & 100.882 & 125.215 & 149.549 \\
\hline Gunung Sahilan & 2.246 & 2.702 & 3.287 & 4.015 & 4.911 \\
\hline Kampar Kiri Tengah & 199.229 & 325.965 & 450.674 & 575.382 & 700.090 \\
\hline XIII Koto Kampar & 82.125 & 90.960 & 99.216 & 107.472 & 115.728 \\
\hline Koto Kampar Hulu & 10.646 & 10.646 & 10.646 & 10.646 & 10.646 \\
\hline Kuok & 182.500 & 228.415 & 288.596 & 348.778 & 408.959 \\
\hline alo & 246.375 & 239.260 & 239.108 & 240.294 & 242.648 \\
\hline pung & 8 & 326. & 9 & 3 & 520.487 \\
\hline Tapung Hulu & 6 & 6 & 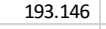 & 6 & 193.146 \\
\hline Tapung Hilir & 453.208 & 461.899 & 469.720 & 477.542 & 485.363 \\
\hline Bangkinang Kota & 39.542 & 41.135 & 42.873 & 44.611 & 46.349 \\
\hline Bangkinang Sebera & 343.708 & 298.445 & 276.719 & 254.993 & 233.267 \\
\hline Kampar & 174.896 & 236.960 & 298.445 & 359.931 & 421.416 \\
\hline Kampa & 51778 & 7 & 73.290 & 84.153 & 95.016 \\
\hline Rumbio Jaya & 202.271 & 228.415 & 250.575 & 272.736 & 294.897 \\
\hline Kampar Utara & 91.250 & 142.813 & 204.733 & 266.653 & 328.572 \\
\hline Tamb & 190. & 287. & 393.316 & 499.340 & 605.364 \\
\hline Siak Hulu & 719.354 & 887.587 & 1.106 .370 & 1.325 .153 & 1.543 .936 \\
\hline Perhentian & & 43.742 & 47.218 & 50.694 & 54.171 \\
\hline Jumlah & 690.267 & 4.367.114 & 5.142 .086 & 5.918 .538 & 6.696 .326 \\
\hline Max & 719.354 & 887.587 & 1.106 .370 & 1.325.153 & 1.543 .936 \\
\hline Min & 2.246 & 2.702 & 3.287 & 4.015 & 4.911 \\
\hline
\end{tabular}

Tabel 13 Kebutuhan Air Ternak

\begin{tabular}{|c|c|c|c|c|c|c|}
\hline \multirow{2}{*}{ Tahun } & \multicolumn{2}{|c|}{ Sapi dan Kerbau } & \multicolumn{2}{c|}{ Kambing dan Domba } & \multicolumn{2}{c|}{ Kebutuhan Air Q } \\
\cline { 2 - 7 } & Jumlah & q & Jumlah & q & 1/hari & m3/hari \\
\hline 2014 & 4.800 & 40 & 1.404 & 5 & 199.020 & 199,02 \\
\hline 2015 & 4.745 & 40 & 1.580 & 5 & 197.700 & 197,70 \\
\hline 2016 & 4.329 & 40 & 1.171 & 5 & 179.015 & 179,02 \\
\hline 2017 & 5.381 & 40 & 736 & 5 & 218.920 & 218,92 \\
\hline 2018 & 5.655 & 40 & 742 & 5 & 229.910 & 229,91 \\
\hline 2019 & 5.727 & 40 & 754 & 5 & 232.850 & 232,85 \\
\hline
\end{tabular}


Tabel 14 Proyeksi Volume Kebutuhan Air Kabupaten Kampar untuk Peternakan Ratarata Pertahun $\left(\mathrm{m}^{3}\right)$

\begin{tabular}{|c|c|c|c|c|c|}
\hline Tahun & 2017 & 2022 & 2027 & 2032 & 2037 \\
\hline Kampar Kiri & 7.083 & 8.165 & 9.265 & 10.377 & 11.494 \\
\hline Kampar Kiri Hulu & 1.596 & 1.702 & 1.851 & 2.010 & 2.177 \\
\hline Kampar Kiri Hilir & 1.778 & 1.683 & 1.696 & 1.715 & 1.739 \\
\hline Gunung Sahilan & 65.396 & 78.732 & 112.123 & 144.877 & 190.864 \\
\hline Kampar Kiri Tengah & 3.280 & 2.956 & 2.713 & 2.477 & 2.245 \\
\hline XIII Koto Kampar & 1.506 & 1.239 & 1.030 & 862 & 724 \\
\hline Koto Kampar Hulu & 1.606 & 1.306 & 1.068 & 876 & 720 \\
\hline Kuok & 2.854 & 2.780 & 2.835 & 2.901 & 2.974 \\
\hline Salo & 2.850 & 2.320 & 1.895 & 1.551 & 1.271 \\
\hline Tapung & 6.680 & 10.148 & 15.437 & 23.511 & 35.841 \\
\hline Tapung Hulu & 9.074 & 17.119 & 32.756 & 63.080 & 121.832 \\
\hline Tapung Hilir & 10.429 & 22.307 & 48.191 & 104.441 & 226.578 \\
\hline Bangkinang Kota & 260 & 133 & 68 & 35 & 18 \\
\hline Bangkinang Seberang & 3.959 & 3.386 & 2.905 & 2.498 & 2.151 \\
\hline Kampar & 1.828 & 1.656 & 1.513 & 1.392 & 1.286 \\
\hline Kampa & 4.801 & 6.793 & 9.687 & 13.861 & 19.861 \\
\hline Rumbio Jaya & 1.994 & 2.201 & 2.455 & 2.750 & 3.086 \\
\hline Kampar Utara & 1.902 & 2.002 & 2.130 & 2.280 & 2.448 \\
\hline Tambang & 2.543 & 2.311 & 2.112 & 1.937 & 1.780 \\
\hline Siak Hulu & 2.923 & 2.743 & 2.589 & 2.452 & 2.328 \\
\hline $\mathrm{Pe}$ & 607 & 5 & 33 & 146 & 91 \\
\hline Jumla & 134.948 & 172.056 & 254.552 & 386.030 & 631.511 \\
\hline Max & 65.396 & 78.732 & 112.123 & 144.877 & 226.578 \\
\hline Min & 260 & 133 & 68 & 35 & 18 \\
\hline
\end{tabular}

\subsection{Kebutuhan Air untuk Perikanan}

Debit air yang baik untuk kolam tidak kurang dari 10 - 15 lt/dt/ha. Pada Analisa ini, debit air untuk kebutuhan perikanan diambil sebesar 15 It/dt/ha. Kebutuhan air untuk perikanan rata-rata pertahun untuk semua wilayah kecamatan di Kabupaten Kampar dapat dilihat pada Tabel 15. Berdasarkan Tabel 15 dapat dilihat bahwa kebutuhan air perikanan yang terbesar yaitu di Kecamatan Kampar dan kebutuhan air Perikanan yang terkecil terdapat di Kecamatan Tapung Hulu.

Tabel 15 Proyeksi Volume Kebutuhan Air Perikanan Kabupaten Kampar Rata-rata Pertahun $\left(\mathrm{m}^{3}\right)$

\begin{tabular}{|c|c|c|c|c|c|}
\hline Tahun & 2017 & 2022 & 2027 & 2032 & 2037 \\
\hline Kampar Kiri & 4.545 .914 & 4.899.437 & 5.185 .401 & 5.471 .365 & 5.757 .329 \\
\hline Kampar Kiri Hulu & 470.675 & 507.204 & 536.769 & 566.334 & 595.899 \\
\hline Kampar Kiri Hilir & 502.211 & 540.692 & 571.778 & 602.863 & 633.949 \\
\hline Gunung Sahilan & 442.292 & 477.020 & 505.120 & 533.221 & 561.322 \\
\hline Kampar Kiri Tengah & 222.723 & 239.993 & 253.959 & 267.925 & 281.891 \\
\hline XIII Koto Kampar & 7.150 .394 & 7.660 .432 & 8.071 .020 & 8.481 .607 & 8.892 .195 \\
\hline Koto Kampar Hulu & 216.416 & 233.329 & 247.013 & 260.698 & 274.382 \\
\hline Kuok & 5.054 .038 & 5.405 .252 & 5.687 .443 & 5.969 .633 & 6.251 .824 \\
\hline Salo & 2.392 .794 & 2.578 .819 & 2.729 .291 & 2.879 .762 & 3.030 .234 \\
\hline Tapung & 419.429 & 452.354 & 478.991 & 505.627 & 532.264 \\
\hline Tapung Hulu & 174.631 & 171.646 & 165.846 & 160.045 & 154.245 \\
\hline Tapung Hilir & 192.370 & 207.124 & 219.063 & 231.001 & 242.940 \\
\hline Bangkinang Kota & 934.648 & 971.102 & 1.001 .230 & 1.031 .359 & 1.061.487 \\
\hline Bangkinang Seberang & 1.272 .083 & 1.371 .403 & 1.451 .764 & 1.532.124 & 1.612.484 \\
\hline Kampar & 8.024 .335 & 8.599 .830 & 9.062 .508 & 9.525.186 & 9.987.864 \\
\hline Kampa & 707.589 & 760.787 & 803.699 & 846.610 & 889.522 \\
\hline Rumbio Jaya & 310.630 & 333.080 & 351.157 & 369.234 & 387.311 \\
\hline Kampar Utara & 713.896 & 768.371 & 812.352 & 856.334 & 900.315 \\
\hline Tambang & 841.617 & 903.976 & 954.264 & 1.004 .553 & 1.054 .842 \\
\hline Siak Hulu & 1.159 .736 & 1.246 .160 & 1.315 .821 & 1.385.482 & 1.455.142 \\
\hline Perhentian Raja & 176.602 & 188.991 & 198.958 & 208.926 & 218.894 \\
\hline Jumlah & 35.925 .023 & 38.517 .000 & 40.603 .445 & 42.689 .889 & 44.776 .333 \\
\hline $\operatorname{Max}$ & 8.024.335 & 8.599 .830 & 9.062 .508 & 9.525.186 & 9.987.864 \\
\hline Min & 174.631 & 171.646 & 165.846 & 160.045 & 154.245 \\
\hline
\end{tabular}

\subsection{Kebutuhan Air untuk Perkebunan}

Pada Analisa ini, kebutuhan air untuk perkebunan hanya menganalisa kebutuhan air untuk Perkebunan Karet dan Perkebunan Kelapa Sawit. Kebutuhan air untuk Karet sebesar 34.889 It/ha/hari dan kebutuhan air untuk Sawit sebesar 7.327 It/ha/hari.

Kebutuhan air untuk perkebunan rata-rata pertahun untuk semua wilayah kecamatan di Kabupaten Kampar dapat dilihat pada Tabel 16. Berdasarkan Tabel 16 dapat dilihat bahwa kebutuhan air untuk perkebunan pada Kabupaten Kampar yang terbesar yaitu di Kecamatan XII Koto Kampar, Kampar Kiri Hulu serta Kecamatan Kampar Kiri dan kebutuhan air perkebunan yang terkecil terdapat di Kecamatan Bangkinang Kota dan Kampar Kiri Tengah.

Tabel 16 Proyeksi Volume Kebutuhan Air Perkebunan Kabupaten Kampar Rata-rata Pertahun $\left(\mathrm{m}^{3}\right)$

\begin{tabular}{|l|r|r|r|r|r|}
\hline \multicolumn{1}{|c|}{ Tahun } & \multicolumn{1}{|c|}{2017} & \multicolumn{1}{c|}{$\mathbf{2 0 2 2}$} & \multicolumn{1}{c|}{$\mathbf{2 0 2 7}$} & \multicolumn{1}{c|}{2032} & \multicolumn{1}{c|}{2037} \\
\hline Kampar Kiri & 14.797 .027 & 16.052 .823 & 17.331 .648 & 18.634 .579 & 19.962 .745 \\
\hline Kampar Kiri Hulu & 16.702 .399 & 16.986 .813 & 17.304 .821 & 17.622 .829 & 17.940 .836 \\
\hline Kampar Kiri Hilir & 3.549 .746 & 3.854 .926 & 4.124 .076 & 4.393 .225 & 4.662 .375 \\
\hline Gunung Sahilan & 4.103 .871 & 5.094 .619 & 6.052 .267 & 7.009 .915 & 7.967 .563 \\
\hline Kampar Kiri Tengah & 3.222 .020 & 2.793 .277 & 2.373 .175 & 1.953 .073 & 1.532 .971 \\
\hline XIII Koto Kampar & 16.607 .083 & 16.875 .280 & 17.135 .645 & 17.396 .009 & 17.656 .373 \\
\hline Koto Kampar Hulu & 6.902 .668 & 6.982 .640 & 7.066 .653 & 7.150 .667 & 7.234 .681 \\
\hline Kuok & 8.055 .729 & 9.048 .296 & 9.853 .483 & 10.658 .671 & 11.463 .858 \\
\hline Salo & 3.353 .513 & 3.479 .817 & 3.624 .565 & 3.769 .313 & 3.914 .062 \\
\hline Tapung & 8.552 .776 & 8.638 .035 & 8.727 .012 & 8.819 .943 & 8.917 .078 \\
\hline Tapung Hulu & 12.991 .716 & 13.095 .208 & 13.199 .815 & 13.305 .498 & 13.412 .216 \\
\hline Tapung Hilir & 9.115 .166 & 10.548 .480 & 11.981 .795 & 13.415 .109 & 14.848 .423 \\
\hline Bangkinang Kota & 1.740 .413 & 1.807 .191 & 1.861 .589 & 1.915 .986 & 1.970 .384 \\
\hline Bangkinang Seberang & 4.350 .980 & 5.614 .107 & 6.881 .782 & 8.149 .457 & 9.417 .132 \\
\hline Kampar & 4.666 .498 & 5.016 .178 & 5.370 .962 & 5.725 .746 & 6.080 .529 \\
\hline Kampa & 2.783 .004 & 2.931 .174 & 3.099 .911 & 3.268 .648 & 3.437 .385 \\
\hline Rumbio Jaya & 2.764 .276 & 2.785 .180 & 2.806 .033 & 2.826 .886 & 2.847 .739 \\
\hline Kampar Utara & 5.100 .193 & 5.275 .250 & 5.429 .739 & 5.584 .228 & 5.738 .717 \\
\hline Tambang & 7.535 .152 & 8.956 .082 & 10.350 .885 & 11.745 .689 & 13.140 .492 \\
\hline Siak Hulu & 9.225 .060 & 10.370 .394 & 11.503 .801 & 12.637 .209 & 13.770 .617 \\
\hline Perhentian Raja & 2.133 .808 & 2.176 .842 & 2.218 .967 & 2.261 .093 & 2.303 .218 \\
\hline Jumlah & 148.253 .099 & 158.382 .611 & 168.298 .624 & 178.243 .771 & 188.219 .394 \\
\hline Max & 16.702 .399 & 16.986 .813 & 17.331 .648 & 18.634 .579 & 19.962 .745 \\
\hline Min & 1.740 .413 & 1.807 .191 & 1.861 .589 & 1.915 .986 & 1.532 .971 \\
\hline
\end{tabular}

\subsection{Analisis Neraca Air}

Analisis neraca air dilakukan dengan pengurangan debit ketersediaan dengan Metode regional terhadap debit total seluruh jenis kebutuhan meliputi kebutuhan penduduk, irigasi, perikanan, perkebunan, peternakan dan pemeliharaan sungai. Analisis neraca air pada penelitian ini dilakukan pada perhitungan yang sudah diproyeksi hingga tahun 2037 dengan asumsi proyeksi pada kebutuhan air penduduk, kebutuhan air ternak, kebutuhan air industry, kebutuhan air perikanan dan kebutuhan air perkebunan. Sedangkan untuk kebutuhan air 
irigasi diasumsikan konstan yang dihitung berdasarkan data terakhir saat ini yang diperoleh dari Badan Pusat Statistik Kabupaten Kampar.

Analisis neraca air dilakukan untuk 20 tahun mendatang yaitu tahun 2037 dihitung berdasarkan probabilitas $80 \%$, probabilitas $20 \%$ serta dihitung berdasarkan Qinflow normal yang diambil dari rata-rata debit dari seluruh debit ketersediaan setiap kecamatan di Kabupaten Kampar. Rekapitulasi kebutuhan

dan ketersediaan air total untuk Kabupaten kampar dapat dilihat pada Tabel 17 (terlampir). Berdasarkan Tabel 17 menunjukkan neraca air pada tahun 2037 hasilnya memberikan perubahan yang jauh dikarenakan kebutuhan yang berubah sangat signifikan pada kebutuhan industry, perkebunan dan perikanan karna setiap tahun selalu meningkat. Perubahan lahan yang terjadi terhadap pembangunan industri sangat berdampak terhadap ketersediaan air pada Kabupaten Kampar, maka dari itu perlu nya tata guna lahan yang teratur dan penggunaan air terhadap daerah sekitar DAS Kampar dan DAS Siak harus dikendalikan dengan baik dan harus terjaga supaya tidak terjadi kekeringan

Penggunaan Sumber Daya Air di Kabupaten Kampar seperti yang terlihat pada Tabel 18 dapat dilihat bahwa kebutuhan air terbesar yaitu untuk perkebunan dan kebutuhan air terkecil yaitu untuk peternakan.

Dari hasil perhitungan didapat daerah layanan yang mengalami defisit air pada 20 tahun mendatang adalah Kecamatan Tapung Hilir dan Kecamatan Kampar. Kebutuhan air yang mendominasi penggunaan air permukaan di Kabupaten Kampar adalah kebutuhan air irigasi dan perkebunan. Keadaan ini ditunjang dengan belum dimanfaatkan dan minimnya sarana bangunan air dari sumber-sumber air lainnya. Oleh sebab itu direkomendasikan agar dilakukan studi dan survey lebih lanjut dari aspek topografi, geologi, hidrologi untuk mengatasi penyediaan air pada daerah defisit, baik interkoneksi dari daerah surplus ke daerah defisit serta perlu dilakukan studi, survey dan investigasi lebih lanjut untuk mencari sumber air baru (bawah permukaan, permukaan) sebagai pemenuhan kebutuhan domestik dan non domestic
Tabel 18 Penggunaan Sumber Daya Air di Kabupaten Kampar

\begin{tabular}{|l|r|r|r|r|r|}
\hline \multirow{nyyyyyy}{*}{ Penggunaan } & \multicolumn{1}{|c|}{2017} & \multicolumn{1}{c|}{2022} & \multicolumn{1}{c|}{2027} & \multicolumn{1}{c}{2032} & \multicolumn{1}{c|}{2037} \\
\hline Irigasi & 22.391 .782 & \multicolumn{1}{c}{22.384 .668} & 22.384 .516 & 22.385 .701 & 22.388 .055 \\
\hline Penduduk (Domestik) & 3.889 .618 & 4.432 .171 & 5.031 .694 & 5.704 .186 & 6.460 .267 \\
\hline Perkotaan (Non Domestik) & 1.162 .869 & 1.434 .681 & 1.706 .493 & 1.978 .305 & 2.250 .117 \\
\hline Industri & 3.690 .267 & 4.367 .114 & 5.142 .086 & 5.918 .538 & 6.696 .326 \\
\hline Peternakan & 134.948 & 172.056 & 254.552 & 386.030 & 631.511 \\
\hline Perikanan & 35.925 .023 & 38.517 .000 & 40.603 .445 & 42.689 .889 & 44.776 .333 \\
\hline Perkebunan & 148.253 .099 & 158.382 .611 & 168.298 .624 & 178.243 .771 & 188.219 .394 \\
\hline Total & 215.447 .606 & 229.690 .301 & 243.421 .409 & 257.306 .421 & 271.422 .004 \\
\hline
\end{tabular}

\section{PENUTUP}

\subsection{Kesimpulan}

Hasil dari perhitungan dan analisis yang telah dilakukan dapat diambil kesimpulan sebagai berikut.

1. Kebutuhan air pada Kabupaten Kampar yaitu diantara lain kebutuhan air irigasi 22.391.782 $\mathrm{m}^{3}$ pada tahun 2017 dan 22.388.055 $\mathrm{m}^{3}$ pada tahun 2037; kebutuhan air penduduk (domestic) 3.889.618 $\mathrm{m}^{3}$ pada tahun 2017 dan $6.460 .267 \mathrm{~m}^{3}$ pada tahun 2037, kebutuhan air perkotaan (non domestic) $1.162 .869 \mathrm{~m}^{3}$ pada tahun 2017 dan 2.250.117 $\mathrm{m}^{3}$ pada tahun 2037, kebutuhan air industry 3.690.267 $\mathrm{m}^{3}$ pada tahun 2017 dan $6.696 .326 \mathrm{~m}^{3}$ pada tahun 2037, kebutuhan air peternakan $134.948 \mathrm{~m}^{3}$ pada tahun 2017 dan $631.511 \mathrm{~m}^{3}$ pada tahun 2037, kebutuhan air perikanan $35.925 .023 \mathrm{~m}^{3}$ pada tahun 2017 dan $44.776 .333 \mathrm{~m}^{3}$ pada tahun 2037 dan kebutuhan air perkebunan 148.253.099 $\mathrm{m}^{3}$ pada tahun 2017 dan 188.219.394 $\mathrm{m}^{3}$ pada tahun 2037.

2. Ketersediaan air dihitung dengan membandingkan luas masing-masing kecamatan dengan luas total DAS dikalikan debit pada pos duga air atau dengan cara analisis debit regional, ketersediaan air terbesar untuk probabilitas $80 \%$ untuk DAS Kampar adalah pada bulan Januari dengan nilai sebesar $371,96 \mathrm{~m}^{3} /$ detik dan untuk DAS Siak adalah pada bulan Desember dengan nilai sebesar 18,06

\subsection{Saran}

1. Penelitian selanjutnya harus meninjau semua kebutuhan untuk semua jenis kebutuhan air dan ketersediaan air agar hasil proyeksi menjadi lebih akurat.

2. Berdasarkan kesimpulan, kebutuhan perkebunan sangat signifikan dibanding dengan yang kebutuhan lain. Maka disarankan ada penelitian lebih lanjut tentang kebutuhan perkebunan di Kabupaten Kampar.

3. Berdasarkan penelitian ini supaya dapat menjadi acuan bagi pemerintah setempat untuk dapat mengantisipasi 
pemakaian air pada perkebunan yang cukup tinggi.

\section{DAFTAR PUSTAKA}

[1] Admadhani DN, Haji ATS, Susanawati LD. 2014. Analisis ketersediaan dan kebutuhan air untuk daya dukung lingkungan (studi kasus Kota Malang). Jurnal Sumberdaya Alam dan Lingkungan. 1(3):13- 20.

[2] Asdak, C. (1995). Hidrologi dan Pengelolaan Daerah Aliran Sungai. Yogyakarta: Gadjah Mada University Press.

[3] Bonita, R dan Mardyanto, MA. 2015. Studi water balance air tanah di Kecematan Kejayan, Kabupaten Pasuruan, Provinsi Jawa Timur. Jurnal Teknik ITS. 4(1) : 2301-9271. Chahayati, Cholilul \& Sutrisno. (2014). Pengaruh Devit Air Terhadap Pola Tata Tananm Pada Baku Sawah Di Daerah Irigasi Kebonagung Kabupaten Sumenep. Vol. 2, No. 2, 2339-0719.

[4] Chahayati, Cholilul \& Sutrisno. (2014). Pengaruh Devit Air Terhadap Pola Tata Tananm Pada Baku Sawah Di Daerah Irigasi Kebonagung Kabupaten Sumenep. Vol. 2, No. 2, 2339-0719.

[5] Indra Z, Jasin MI, Binilang A and Mamoto JD. 2012. Analisis debit Sungai Munte dengan metode Mock dan metode NRECA untuk kebutuhan pembangkit listrik tenaga air. Jurnal Sipil Statik.

[6] Islami, Titik. Dan Wani Hadi Utomo, 1995, Hubungan Air Tanah dan Tanaman, IKIP Semarang Press, Semarang.

[7] Lee, R. (1998). Hidrologi Hutan. Yogyakarta: Gadjah Mada University Press.

[8] Mochammad, Taufan L \& dkk. (2013). Studi Optimal Pola Tanam Pada Daerah irigasi Konto Surabaya Dengan Menggunakan Program Linier. Vol.2, No.1, 2337-3539,5.

[9] Pribadi, K., \& Oktavia, P. (2007). Pengelolaan Sumberdaya Air Terpadu Melalui Pengembangan Kebijakan Pembangunan Berkelanjutan di Cekungan Bandung.
[10] Priyonugroho, A. (2014, September). Analisis Kebutuhan Air Irigasi (Studi Kasus pada Daerah Irigasi Sungai Air Keban Daerah Kabupaten Empat Lawang). 2, 1-32.

[11] Purwantara, Suhadi. 2011. Studi temperatur udara terkini di wilayah di Jawa Tengah dan DIY. Informasi.

[12] Purwanto, MYJ. 1995. Water demand for industry, village and city. Di dalam: Purwanto, MYJ. 2007. Kebutuhan Air Sektoral untuk Pengembangan DAS. Agritech. 27(2).

[13] Rumihin, Angel. 2016. Studi pengaruh lining saluran irigasi terhadap kehilangan air untuk peningkatan produksi (studi kasus : di Kairatu I) [tesis]. Surabya (ID) : Institut Teknologi Sepuluh Nopember.

[14] SNI 6728.1:2015. Penyusunan neraca spasial sumber daya alam - Bagian 1 : Sumber daya air.

[15] SNI 6728.1:2015.Tata cara perhitungan evapotranspirasi tanaman acuan dengan metode penman-monteith.

[16] Soemarto. 1995. Hidrologi Teknik. Erlangga, Jakarta.

[17] Sukmanda, B. (2016). Analisa Ketersediaan dan Kebutuhan Air pada daerah aliran sungai percut untuk memenuhi kebutuhan air bersih di kabupaten deli serdang. Medan: Universitas Sumatra Utara.

[18] Sunaryo, Trie M dkk. 2004. Pengelolaan Sumber Daya Air. Malang: Universitas Brawijaya.

[19] Triadmodjo, Bambang. (2016). Hidrologi Terapan. Beta Offeset, Yogyakarta.

[20] Vorosmarty, C], Green, P, Salisbury, ], Lammers, RB, 2000. Global water resources: vulnerability from climate change and population growth. Science.

[21] Yulistiyanto B, Kironoto BA. 2008. Analisa pendayagunaan sumberdaya air pada WS Paguyaman dengan ribasim. Media Teknik.

[22] Zulkipli, Soetopo W, Prasetijo H. 2012. Analisis neraca air permukaan DAS Renggung untuk memenuhi kebutuhan air irigasi dan domestik penduduk Kabupaten Lombok Tengah. Jurnal Teknik Pengairan. 3(2):87-96. 
LAMPIRAN:

Tabel 8 Debit Andalan 80\% (m3/s)

\begin{tabular}{|c|c|c|c|c|c|c|c|c|c|c|c|c|}
\hline \multirow{2}{*}{ Kecamatan } & \multicolumn{12}{|c|}{ Debit Andalan 80} \\
\hline & Jan & Feb & Mar & Apr & Mei & Jun & Jul & Agt & Sep & Okt & Nov & Des \\
\hline Kampar Kiri & 85,12 & 78,64 & 69,59 & 54,53 & 43,83 & 33,18 & 32,19 & 27,50 & 35,79 & 33,43 & 50,75 & 65,45 \\
\hline Kampar Kiri Hulu & 121,00 & 111,79 & 98,93 & 77,53 & 62,30 & 47,17 & 45,76 & 39,10 & 50,89 & 47,52 & 72,15 & 93,04 \\
\hline Kampar Kiri Hilir & 70,65 & 65,27 & 57,76 & 45,26 & 36,38 & 27,54 & 26,72 & 22,83 & 29,71 & 27,74 & 42,12 & 54,32 \\
\hline Gunung Sahilan & 55,60 & 51,37 & 45,46 & 35,63 & 28,63 & 21,67 & 21,03 & 17,97 & 23,38 & 21,84 & 33,16 & 42,75 \\
\hline Kampar Kiri Tengah & 30,74 & 28,40 & 25,13 & 19,70 & 15,83 & 11,98 & 11,63 & 9,93 & 12,93 & 12,07 & 18,33 & 23,64 \\
\hline XIII Koto Kampar & 68,11 & 62,92 & 55,68 & 43,64 & 35,07 & 26,55 & 25,76 & 22,01 & 28,64 & 26,75 & 40,61 & 52,37 \\
\hline Koto Kampar Hulu & 62,67 & 57,90 & 51,24 & 40,16 & 32,27 & 24,43 & 23,70 & 20,25 & 26,36 & 24,61 & 37,37 & 48,19 \\
\hline Kuok & 14,08 & 13,01 & 11,51 & 9,02 & 7,25 & 5,49 & 5,32 & 4,55 & 5,92 & 5,53 & 8,40 & 10,83 \\
\hline Salo & 19,33 & 17,86 & 15,80 & 12,38 & 9,95 & 7,53 & 7,31 & 6,24 & 8,13 & 7,59 & 11,52 & 14,86 \\
\hline Tapung & 9,11 & 6,32 & 7,92 & 8,62 & 8,04 & 4,94 & 4,11 & 4,13 & 6,21 & 7,66 & 12,48 & 14,37 \\
\hline Tapung Hulu & 7,80 & 5,41 & 6,77 & 7,38 & 6,89 & 4,23 & 3,52 & 3,53 & 5,32 & 6,55 & 10,68 & 12,30 \\
\hline Tapung Hilir & 6,76 & 4,69 & 5,87 & 6,39 & 5,97 & 3,67 & 3,05 & 3,06 & 4,61 & 5,68 & 9,26 & 10,66 \\
\hline Bangkinang Kota & 16,48 & 15,22 & 13,47 & 10,56 & 8,48 & 6,42 & 6,23 & 5,32 & 6,93 & 6,47 & 9,82 & 12,67 \\
\hline Bangkinang Seberang & 23,57 & 21,78 & 19,27 & 15,10 & 12,14 & 9,19 & 8,91 & 7,62 & 9,91 & 9,26 & 14,06 & 18,12 \\
\hline Kampar & 12,67 & 11,71 & 10,36 & 8,12 & 6,53 & 4,94 & 4,79 & 4,09 & 5,33 & 4,98 & 7,56 & 9,74 \\
\hline Kampa & 16,09 & 14,87 & 13,16 & 10,31 & 8,29 & 6,27 & 6,09 & 5,20 & 6,77 & 6,32 & 9,60 & 12,38 \\
\hline Rumbio Jaya & 7,15 & 6,61 & 5,85 & 4,58 & 3,68 & 2,79 & 2,71 & 2,31 & 3,01 & 2,81 & 4,26 & 5,50 \\
\hline Kampar Utara & 7,42 & 6,86 & 6,07 & 4,76 & 3,82 & 2,89 & 2,81 & 2,40 & 3,12 & 2,92 & 4,43 & 5,71 \\
\hline Tambang & 34,59 & 31,95 & 28,28 & 22,16 & 17,81 & 13,48 & 13,08 & 11,18 & 14,55 & 13,58 & 20,62 & 26,59 \\
\hline Siak Hulu & 64,14 & 59,26 & 52,44 & 41,10 & 33,03 & 25,00 & 24,26 & 20,73 & 26,98 & 25,19 & 38,25 & 49,32 \\
\hline Perhentian Raja & 10,37 & 9,58 & 8,48 & 6,65 & 5,34 & 4,04 & 3,92 & 3,35 & 4,36 & 4,07 & 6,18 & 7,97 \\
\hline
\end{tabular}

Tabel 17. Neraca Air pada Kabupaten Kampar untuk saat ini, 2, 5, 10 dan 20 tahun mendatang

\begin{tabular}{|c|c|c|c|c|c|c|c|c|c|c|c|}
\hline \multirow{2}{*}{ Kecamatan } & \multirow{2}{*}{$\begin{array}{c}\text { Air } \\
\text { (m3/tahun) }\end{array}$} & \multicolumn{5}{|c|}{ Kebutuhan Air (m3/tahun) } & \multicolumn{5}{|c|}{ Neraca (m3/tahun) } \\
\hline & & 2017 & 2022 & 2027 & 2032 & 2037 & 2017 & 2022 & 2027 & 2032 & 2037 \\
\hline Kampar Kiri & 133.197.334 & 20.014 .025 & 21.659 .332 & 23.260 .127 & 24.885 .039 & 26.535 .193 & 113.183.309 & 111.538 .002 & 109.937.207 & 108.312 .294 & 106.662 .140 \\
\hline Kampar Kiri Hulu & 189.355 .785 & 17.268 .670 & 17.600 .024 & 17.958 .049 & 18.316 .085 & 18.674 .128 & 172.087 .115 & 171.755 .761 & 171.397 .736 & 171.039 .699 & 170.681 .656 \\
\hline Kampar Kiri Hilir & 110.556 .130 & 4.234 .254 & 4.607 .688 & 4.938 .818 & 5.269 .954 & 5.601 .094 & 106.321 .875 & 105.948 .441 & 105.617.312 & 105.286 .176 & 104.955 .036 \\
\hline Gunung Sahilan & 87.015 .622 & 4.743 .403 & 5.807 .718 & 6.851 .861 & 7.895 .510 & 8.952 .559 & 82.272 .219 & 81.207 .904 & 80.163 .761 & 79.120 .112 & 78.063 .063 \\
\hline Kampar Kiri Tengah & 48.106.919 & 3.817 .616 & 3.588 .646 & 3.356 .938 & 3.125 .236 & 2.893 .538 & 44.289 .304 & 44.518 .273 & 44.749 .982 & 44.981 .683 & 45.213 .381 \\
\hline XIII Koto Kampar & 106.577 .657 & 24.131 .449 & 24.934 .256 & 25.630 .611 & 26.328 .506 & 27.028 .090 & 82.446 .208 & 81.643 .401 & 80.947 .046 & 80.249 .152 & 79.549 .567 \\
\hline Koto Kampar Hulu & 98.079 .384 & 7.849 .564 & 7.958 .323 & 8.068 .955 & 8.180 .737 & 8.293 .773 & 90.229 .820 & 90.121 .061 & 90.010 .429 & 89.898 .647 & 89.785 .612 \\
\hline Kuok & 22.032 .937 & 15.892 .796 & 17.298 .539 & 18.463 .594 & 19.630 .114 & 20.798 .245 & 6.140 .142 & 4.734 .398 & 3.569 .343 & 2.402 .823 & 1.234 .692 \\
\hline Salo & 30.243 .084 & 6.405 .591 & 6.720 .165 & 7.033 .080 & 7.350 .324 & 7.671 .708 & 23.837.492 & 23.522.919 & 23.210 .004 & 22.892 .760 & 22.571 .376 \\
\hline Tapung & 20.590 .253 & 10.050 .387 & 10.332 .238 & 10.614 .246 & 10.914 .398 & 11.236 .076 & 10.539 .866 & 10.258 .014 & 9.976 .007 & 9.675 .855 & 9.354 .176 \\
\hline Tapung Hulu & 17.623 .443 & 13.940 .796 & 14.143 .147 & 14.365 .027 & 14.618 .794 & 14.921 .087 & 3.682 .647 & 3.480 .296 & 3.258 .416 & 3.004 .649 & 2.702 .356 \\
\hline Tapung Hilir & 15.278 .122 & 10.154 .142 & 11.671 .588 & 13.204 .408 & 14.773 .307 & 16.414 .554 & 5.123 .980 & 3.606 .534 & 2.073 .715 & 504.816 & 1.136 .431 \\
\hline Bangkinang Kota & 25.782 .946 & 965.719 & 3.099 .650 & 217.837 & 3.339 .139 & 3.463 .910 & 22.817 .227 & 22.683 .295 & 22.565 .109 & 22.443 .806 & 22.319 .036 \\
\hline Bangkinang Seberang & 36.888 .908 & 7.707 .527 & 9.044 .484 & 10.392 .258 & 11.741 .864 & 13.093 .464 & 29.181 .381 & 27.844 .424 & 26.496 .650 & 25.147 .044 & 23.795 .444 \\
\hline Kampar & 19.831.244 & 17.700 .375 & 18.717.949 & 19.629 .609 & 20.543 .869 & 21.460 .977 & 2.130 .869 & 1.113 .295 & 201.635 & 712.625 & 1.629 .733 \\
\hline Kampa & 25.186 .320 & 5.753 .718 & 5.987 .207 & 6.233 .983 & 6.484 .247 & 6.738 .827 & 19.432 .602 & 19.199.113 & 18.952 .337 & 18.702 .073 & 18.447 .493 \\
\hline Rumbio Jaya & 11.193 .273 & 4.364 .980 & 4.444 .676 & 4.516 .752 & 4.589 .680 & 4.663 .537 & 6.828 .294 & 6.748 .597 & .676 .522 & 6.603 .594 & 6.529 .736 \\
\hline Kampar Utara & 11.618 .187 & 8.385 .123 & 8.677 .230 & 8.949 .543 & 9.222 .849 & 9.497 .244 & 3.233 .064 & 2.940 .957 & 2.668 .644 & 2.395 .338 & 2.120 .943 \\
\hline Tambang & 54.124 .104 & 15.690 .445 & 17.324 .896 & 18.936 .151 & 20.554 .440 & 22.180 .757 & 38.433 .660 & 36.799.208 & 35.187 .953 & 33.569 .664 & 31.943 .348 \\
\hline Siak Hulu & 100.378 .575 & 11.914 .802 & 13.538 .304 & 15.196 .119 & 16.868 .345 & 18.557 .251 & 88.463 .772 & 86.840 .271 & 85.182 .455 & 83.510 .230 & 81.821 .323 \\
\hline Perhentian Raja & 16.231.119 & 2.462 .225 & 2.534 .240 & 2.603 .442 & 2.673 .983 & 2.745 .992 & 13.768 .894 & 13.696 .879 & 13.627 .678 & 13.557 .136 & 13.485 .127 \\
\hline
\end{tabular}

